\title{
Bahaya Kecanduan Internet dan Kecemasan Komunikasi terhadap Karakter Kerja Sama pada Mahasiswa
}

\author{
Noviana Dewi'; Stefanus Khrismasagung Trikusumaadi ${ }^{2}$ \\ STIKES Nasional
}

\begin{abstract}
This research aims at investigating the correlation of internet addiction and communication anxiety to cooperative character of students. Its subjects were 90 students. The research used the survey method with questionnaire with Likert model scale. Its data were collected through Internet Addiction Test (IAT) with the aspects: of attention centered on internet, longer time spent, less control, agitated feeling during offline, satisfaction-increasing internet, internet as compensation, compulsive behavior, withdrawal, social risk occurrence, and frequent lying. The anxiety scales included unwilling to communicate, avoiding participation, less self-control. The character scales included cooperating with others, raising positive hopes, appreciating inputs and feedbacks, giving encouragements, and cultivating spirits. The data were analyzed by using the multiple linear regression analysis aided with SPSS 19. There was correlation between the two independent variables and the dependent variable
\end{abstract}

Keywords: communication anxiety, cooperative character, internet addiction

\begin{abstract}
Abstrak. Penelitian ini bertujuan untuk mengetahui hubungan kecanduan internet dan kecemasan komunikasi dengan karakter kerja sama pada mahasiswa. Subjek dalam penelitian ini adalah 90 mahasiswa. Data dalam penelitian ini diperoleh dengan menggunakan Internet Addiction Test (IAT) dengan aspek-aspek meliputi perhatian terpusat pada internet, waktu berinternet semakin lama, kurang kontrol, gelisah saat offline, internet meningkatkan kepuasan, internet sebagai pelarian, compulsif, withdrawl, muncul resiko sosial, sering berbohong. Skala kecemasan komunikasi dengan aspekaspek meliputi tidak ingin berkomunikasi, menghindari partisipasi, kurang kontrol diri. Skala karakter kerja sama dengan aspek-aspek meliputi bekerja bersama, memunculkan harapan positif, menghargai masukan, memberikan dorongan serta menumbuhkan semangat. Data yang diperoleh kemudian dianalisis dengan menggunakan analisis regresi linier berganda hasilnya terdapat hubungan antara kecanduan internet dan kecemasan komunikasi dengan karakter kerja sama pada mahasiswa.
\end{abstract}

Kata kunci: internet addiction, kecemasan komunikasi, kerja sama

Idealnya peserta didik kelak akan terjun ke masyarakat dan menggunakan ilmu yang telah diperoleh untuk kesejahteraan masyarakat. Untuk dapat terjun ke masyarakat peserta didik harus dibekali

\footnotetext{
${ }^{1}$ Korespondensi mengenai isi artikel ini dapat dilakukan melalui: viana072@gmail.com
}

kemampuan sosial dan etika bermasyarakat. Menurut Clarken (2010) terdapat empat aspek yang dapat menunjukkan orang tersebut memiliki kecerdasan moral yang bagus yaitu aspek integritas, tanggung jawab, pemaaf, dan memiliki kepedulian pada sesama. 
Urgensi untuk membentuk karakter peserta didik juga tertuang dalam UU Pendidikan Tinggi. Pada pasal 3 disebutkan bahwa asas dalam menjalankan pendidikan tinggi ada sembilan di antaranya kebenaran ilmiah, penalaran, kejujuran, keadilan, manfaat, kebajikan, tanggung jawab, kebhinekaan, dan keterjangkauan. Pada kesembilan asas pendidikan tinggi tersebut terdapat nilainilai karakter penting seperti jujur, adil, dan tanggung jawab. Selain pada pasal 3, pada pasal 4 juga dijelaskan bahwa pendidikan tinggi seharusnya memiliki tiga fungsi yaitu: mengembangkan kemampuan dan membentuk watak serta peradaban bangsa yang bermartabat dalam rangka mencerdaskan kehidupan bangsa; mengembangkan civitas akademika yang kreatif, inovatif, responsif, terampil, berdaya saing, dan kooperatif melalui pelaksanaan Tri Dharma; dan mengembangkan ilmu pengetahuan dan teknologi dengan memperhatikan dan menerapkan nilai humaniora. Telah dijelaskan pada pasal sebelumnya bahwa humaniora adalah disiplin akademik yang mengkaji nilai intrinsik kemanusiaan (UU RI No.12 Tahun 2012 Tentang Pendidikan Tinggi). Berdasarkan kajian terhadap UU tentang pendidikan tinggi dapat dipahami bahwa pendidikan khususnya pendidikan tinggi memiliki peranan penting dalam menyiapkan peserta didik yang akan terjun ke dunia kerja dan masyarakat. Peranan tersebut tidak hanya membekali mahasiswanya dengan ilmu yang up to date sesuai dengan permintaan pasar tenaga kerja tetapi juga membekali mahasiswanya dengan kemampuan menjadi makhluk sosial yang mampu menerapkan nilai humaniora serta mampu mengaplikasikan ilmu yang diperoleh bagi kehidupan bermasyarakat secara bertanggung jawab.
Menurut Ikhwanuddin (2011) manusia merupakan makhluk sosial yang dalam kesehariannya akan senantiasa bekerja sama dengan manusia lainnya sehingga karakter kerja sama mutlak dibutuhkan agar dapat hidup sebagai makhluk sosial yang utuh. Departemen Health and Human Services Amerika Serikat menyatakan pentingnya kemampuan psikososial, khususnya emosi dan sosial, yang meliputi: percaya diri, kemampuan kontrol diri, kemampuan bekerja sama, kemudahan bergaul, kemampuan berkonsentrasi, rasa empati, dan kemampuan berkomunikasi.

Zuchdi dkk (2009) menyatakan ada beberapa nilai yang perlu dipelajari dan diajarkan di sekolah, yang dinamai sebagai Mega Skills, antara lain: percaya diri, motivasi, usaha, tanggung jawab, inisiatif, kemauan kuat, kasih sayang, dan kerja sama. Karakter kerja sama merupakan karakter yang harus dimiliki agar dapat hidup berdampingan dengan baik antara individu yang satu dengan individu yang lain. Namun demikian terkadang terdapat benturan dan konflik ketika individu yang satu dengan individu yang lain harus bekerja sama. Hal ini dikarenakan terdapat beberapa kemampuan yang tidak dimiliki individu dalam bersosialisasi diantaranya yaitu kemampuan untuk berkomunikasi dan kemampuan untuk berinteraksi.

Dewasa ini seiring dengan pesatnya perkembangan teknologi menyebabkan dunia semakin tanpa batas. Internet dapat diakses dengan mudah dimana pun dan kapan pun sebagai sarana berkomunikasi dan berinteraksi dengan orang lain. Namun demikian dengan kecanggihan teknologi tersebut menyebabkan antara indivu yang satu dengan individu yang lain justru semakin jarang berinteraksi secara langsung karena lebih nyaman berinteraksi melalui dunia maya dengan 
menggunakan internet. Padahal menurut Young (1998) kecanduan internet berpotensi melumpuhkan kepribadian individu. Individu yang sebenarnya mampu berinteraksi dengan baik dalam dunia nyata cenderung memilih berinteraksi melalui dunia maya karena kenyamanan yang ditawarkan. Akibatnya, kemampuan individu untuk berinteraksi dan bersosialisasi menjadi tumpul.

Adiksi komputer merupakan adiksi obsesif terhadap penggunaan komputer. Dewi (2011) menyatakan bahwa seseorang bisa menderita adiksi kepada komputer dan mengalami gejala-gejala withdrawl bila menghentikan kegiatan tersebut. Bentuk lain adiksi ini meliputi adiksi internet dan video game. Akibat adiksi ini akan menimbulkan masalah akademis dan fungsi hubungan sosial lainnya. Pola kecanduan internet nampak mirip dengan gejala kecanduan pada zat psikoaktif, dengan demikian, dapat dikatakan bahwa kecanduan internet merupakan pola kecanduan yang sudah dikenal sejak lama dengan objek yang lebih modern.

Selain interaksi yang terbatas akibat kecanduan internet, kemampuan komunikasi juga dibutuhkan untuk dapat bekerja sama dengan individu lain. Tanpa kemampuan komunikasi mustahil kerja sama dapat terjalin. Mahasiswa sains dalam hal ini analis kesehatan cenderung bagus hal kognitif namun kurang dalam hal sosialisasi. Lemahnya kemampuan komunikasi petugas kesehatan baik verbal maupun non verbal saat ini menjadi permasalahan utama yang menyebabkan munculnya sejumlah kasus. Rendahnya kemampuan komunikasi disebabkan banyak hal salah satunya kecemasan komunikasi. Menurut Gudykunst (2002) kecemasan adalah dasar penyebab kegagalan komunikasi. Kecemasan memengaruhi kemampuan individu untuk dapat berkomunikasi secara efektif dan menyesuaikan diri dengan lingkungan yang baru.

Kerja sama adalah keinginan untuk bekerja sama dengan orang lain secara kooperatif dan menjadi bagian dari kelompok. Bukan bekerja secara terpisah atau saling berkompetisi. Kompetensi kerja sama menekankan peran sebagai anggota kelompok, bukan sebagai pemimpin. Kelompok di sini dalam arti yang luas, yaitu sekelompok individu yang menyelesaikan suatu tugas atau proses (Spencer \& Spencer, 1993).

Dorongan atau kemampuan untuk bekerja sama dengan orang lain, dorongan atau kemampuan untuk menjadi bagian dari suatu kelompok dalam melaksanakan suatu tugas (Kesuma, Triatna, dan Permana, 2011). Tindakan dan sikap mau bekerja sama dengan orang lain untuk mencapai tujuan bersama dan keuntungan bersama.

Menurut Ikhwanuddin (2011) karakter kerja sama dipengaruhi oleh empat faktor utama yang meliputi: pembagian peran agar masing-masing individu dapat melaksanakan tugasnya masing-masing sesuai perannya. Pembagian peran seharusnya dilakukan sesuai porsi sehingga dapat saling berkontribusi secara optimal; kemampuan komunikasi efektif agar kerja sama dapat berjalan lancar. Hambatan dalam komunikasi dapat menyebabkan kendala dalam proses kerja sama. Tanpa kemampuan komunikasi yang efektif akan sulit bekerja sama secara optimal antara individu yang satu dengan individu yang lain; interaksi sosial antara individu yang satu dengan individu yang lain sebagai makhluk sosial. Interaksi merupakan respon yang bersifat dinamis dalam suatu kelompok; kemampuan memberikan inisiatif yang mendukung akan menjadikan kerja sama berjalan harmonis. 
Menurut Spencer \& Spencer (1993) aspek-aspek karakter kerja sama terdiri dari lima hal seperti berikut: bekerja bersama yaitu kemampuan menyelesaikan tugas bersama dalam satu kelompok dengan tujuan yang sama, mengungkapkan harapan yang positif yaitu kemampuan menyampaikan keinginan terhadap kelompok atau tim, menghargai masukan yaitu kemampuan menerima pendapat orang lain dalam kelompok baik positif maupun negatif demi kemajuan kelompok, memberikan dorongan yaitu kemampuan menggerakkan dan mendorong anggota dalam kelompok untuk bersama-sama mencapai tujuan kelompok, dan membangun semangat kelompok yaitu memberikan semangat pada anggota kelompok lain agar senantiasa menjaga motivasi untuk bekerja sama.

Menurut Young (1998) aspek-aspek kecanduan internet meliputi beberapa hal berikut ini: perhatian tertuju pada aktivitas online; ingin bermain internet dalam jumlah waktu yang semakin meningkat untuk mendapatkan kepuasan; tidak dapat mengontrol, mengurangi atau menghentikan kegiatan berinternet; merasa gelisah, tertekan, lekas marah ketika mengurangi atau menghentikan penggunaan internet; online lebih lama dari waktu yang direncanakan; menjadikan internet sebagai cara untuk melepaskan diri dari berbagai permasalahan atau melepaskan diri dari perasaan yang tidak menyenangkan; selalu kembali menggunakan internet walaupun sudah banyak menghabiskan; kecenderungan untuk menarik diri ketika offline; berani mengambil resiko kehilangan hubungan dengan orang terdekat, pekerjaan, pendidikan, atau karir karena bermain internet; berbohong terhadap anggota keluarga untuk mengurangi timgkat hubungan bermain internet.
Menurut Burgoon dan Ruffner (1978) aspek-aspek komunikasi ada tiga seperti berikut ini: unwillingness yaitu ketidaksediaan untuk berkomunikasi yang ditandai dengan kecemasan, intoversi dan rendahnya frekuensi partisipasi dalam berbagai situasi komunikasi; avoiding yaitu penghindaran dari partisipasi karena pengalaman komunikasi yang tidak menyenangkan dengan indikasi kurangnya pengenalan situasi komunikasi yang memengaruhi intimasi dan empati; control yaitu rendahnya pengendalian terhadap situasi komunikasi yang terjadi karena faktor lingkungan, ketidakmampuan menyesuaikan diri dengan individu yang berbeda serta reaksi lawan bicara.

Menurut Dewi (2011) penggunaan internet memiliki dampak terhadap pola perilaku masyarakat di perkotaan. Temuan studi menunjukkan bahwa telah terjadi evolusi penggunaan internet, dari penggunaan untuk fungsi sederhana (komunikasi) menjadi penggunaan dengan fungsi yang spesifik. Temuan studi lainnya menunjukkan bahwa pengguna internet merupakan masyarakat yang berpendidikan tinggi (well educated) dan mampu secara finansial (wellfinanced). Studi tersebut juga menunjukkan dampak yang teridentifikasi akibat penggunaan internet secara intensif dapat dibagi berdasarkan tiga kriteria, yaitu pola pergerakan, pola aktivitas dan implikasinya terhadap interaksi sosial.

Efektivitas komunikasi hanya dapat dicapai bila antara petugas kesehatan dengan klien tercipta kerja sama yang baik untuk mencapai satu tujuan (Basuki, 2010). Tanpa kemampuan berkomunikasi yang efektif antara anggota dalam tim maka kerja sama akan sulit dilakukan. Hambatan dalam komunikasi menyebabkan pesan tidak dapat diserap secara optimal akibatnya informasi yang dibutuhkan 
antara individu dalam satu kelompok terlewatkan satu dengan yang lain sehingga kerja sama tidak berjalan dengan lancar.

Young dan Rodgers (1998) mengemukakan dampak negatif dari internet membuat seseorang menjadi malas untuk berkomunikasi di dunia nyata karena merasa lebih menyenangkan untuk berkomunikasi dengan teman online sehingga mengakibatkan kurangnya rasa empati terhadap lingkungan sekitar. Penderita mencoba mengatasi kecemasan yang dimilikinya dengan melarikan diri dari dunia nyata ke dunia maya akibatnya ketika harus berkomunikasi dengan orang lain di dunia nyata suasana menjadi kaku sehingga kemungkinan untuk menjalin kerja sama pun menjadi semakin kecil.

Karakter kerja sama menurut Kesuma, Triatna, dan Permana (2011) yaitu dorongan atau kemampuan untuk bekerja sama dengan orang lain, dorongan atau kemampuan untuk menjadi bagian dari suatu kelompok dalam melaksanakan suatu tugas, atau tindakan dan sikap mau bekerja sama dengan orang lain untuk mencapai tujuan bersama dan keuntungan bersama. Menurut Ikhwanuddin (2011) karakter kerja sama dipengaruhi oleh empat faktor utama yang meliputi: pembagian peran yaitu bekerja sama membutuhkan pembagian peran agar masingmasing individu dapat melaksanakan tugasnya masing-masing sesuai perannya, pembagian peran seharusnya dilakukan sesuai porsi sehingga dapat saling berkontribusi secara optimal. Komunikasi yaitu kemampuan komunikasi efektif dibutuhkan agar kerja sama dapat berjalan lancar. Hambatan dalam komunikasi dapat menyebabkan kendala dalam proses kerja sama. Tanpa kemampuan komunikasi yang efektif akan sulit bekerja sama secara optimal antara individu yang satu dengan individu yang lain. Interaksi sosial yaitu kerja sama menuntut interaksi antara individu yang satu dengan individu yang lain sebagai makhluk sosial. Interaksi

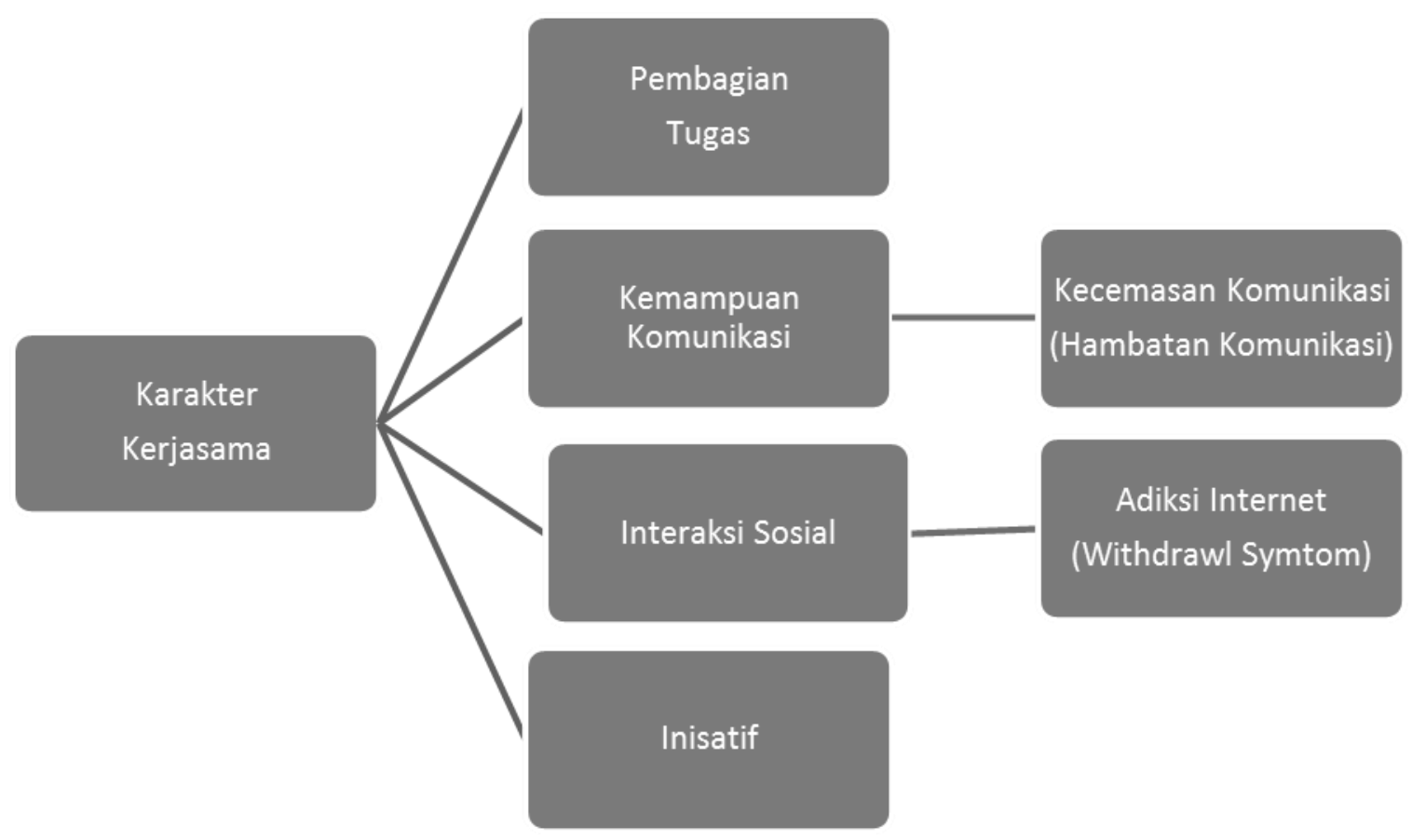

Gambar 1. Faktor-Faktor Karakter Kerja Sama 
merupakan respon yang bersifat dinamis dalam suatu kelompok. Inisiatif yaitu kerja sama melibatkan sejumlah individu yang memungkinkan muncul inisiatif atau ideide kreatif dari masing-masing individu. Kemampuan memberikan inisiatif yang mendukung akan menjadikan kerja sama berjalan harmonis.

\section{Metode}

Penelitian ini memiliki dua variabel bebas dan satu variabel tergantung. Variabel tergantung dalam penelitian ini yaitu karakter kerja sama, sedangkan variabel bebas yang pertama yaitu kecanduan internet dan variabel bebas yang kedua yaitu kecemasan komunikasi.

Populasi pada penelitian ini yaitu seluruh mahasiswa reguler AK Surakarta yang terdiri dari mahasiswa tingkat 1, tingkat 2, dan tingkat 3 dengan total populasi sejumlah 340 mahasiswa. Sampel dalam penelitian ini yaitu sejumlah 90 orang mahasiswa AK Surakarta yang terdiri dari mahasiswa tingkat 1, 2, dan 3. Sampling dilakukan dengan menggunakan teknik kuota non random sampling yaitu masing-masing tingkat diambil 30 mahasiswa.

Pengumpulan data penelitian dilakukan dengan menggunakan metode survey dengan instrument penelitian berupa skala dengan model skala likert. Pada penelitian ini digunakan tiga skala yaitu Internet Addiction Test yang mengacu pada aspek yang dikemukakan oleh Young (1998) meliputi perhatian terpusat pada internet, waktu berinternet semakin lama, kurang kontrol, gelisah saat offline, internet meningkatkan kepuasan, internet sebagai pelarian, compulsif, withdrawl, muncul resiko sosial serta sering berbohong. Skala yang kedua merupakan skala kecemasan komunikasi yang mengacu pada aspek- aspek yang dinyatakan oleh Burgoon dan Ruffner (1978) meliputi tidak ingin berkomunikasi, menghindari partisipasi, serta kurang kontrol diri. Skala yang ketiga ialah skala karakter kerja sama yang mengacu pada aspek yang disampaikan oleh Spencer (1993) meliputi bekerja bersama, memunculkan harapan positif, menghargai masukan, memberikan dorongan serta menumbuhkan semangat.

Penelitian ini merupakan penelitian kuantitatif korelasional yaitu mencari hubungan antara variabel bebas dengan variabel tergantung. Prosedur penelitian meliputi perancangan blue print skala penelitian. Pembuatan skala dan uji coba skala kemudian dilakukan pemilihan aitem yang valid dan reliabel untuk digunakan dalam penelitian yang kemudian disebarkan dan dilakukan olah data statistik.

Berdasarkan hasil pengumpulan data kemudian diolah menggunakan program SPSS.19 yang meliputi hasil uji validitas dan reliabilitas instrument penelitian setelah try out kemudian dilakukan penyusunan ulang menggunakan instrument yang sudah valid dan reliabel untuk pengambilan data penelitian.

Try out dilakukan pada sejumlah 34 mahasiswa tingkat dua. Hasil try out pada skala kecanduan internet dari 20 item yang diajukan terdapat 15 item yang lolos dan 5 item yang gugur. Item yang lolos memiliki skor antara 0,309 sampai 0,819 dengan angka reliabilitas alpha cronbach sebesar 0,885 . Hasil try out pada skala kecemasan komunikasi dari 36 item yang diujikan terdapat 10 item yang gugur dan 26 item yang lolos uji dengan skor antara 0,2740,806 dan reliabilitas alpha cronbach sebesar 0,906 . Hasil try out pada skala karakter kerja sama dari 45 item yang diujikan terdapat 29 item yang lolos dan 16 item yang gugur dengan skor antara 0,201-0,799 
dan angka reliabilitas alpha cronbach 0,879. Skala penelitian kemudian disusun ulang menggunakan item-item yang sudah valid dan reliabel. Data penelitian diambil menggunakan skala penelitian terhadap sejumlah 90 mahasiswa yang menjadi sampel dalam penelitian ini. Data yang terkumpul kemudian dianalisis menggunakan teknik analisis regresi linier berganda untuk mengetahui apakah ada hubungan kecanduan internet dan kecemasan komunikasi dengan karakter kerja sama pada mahasiswa.

\section{Hasil}

Penelitian ini bermaksud untuk menguji hipotesis awal yaitu ada hubungan kecanduan internet dan kecemasan komunikasi dengan karakter kerja sama pada mahasiswa. Pengujian hipotesis dilakukan dengan menggunakan teknik analisis regresi linier berganda. Hasil uji analisis regresi linier berganda menunjukkan bahwa terdapat korelasi yang kuat antara kedua variabel bebas terhadap variabel tergantung yaitu ditunjukkan dengan koefisien korelasi sebesar 0,943.

Berdasarkan hasil uji statistik menggunakan teknik analisis regresi linier berganda hipotesis yang diajukan dalam penelitian ini diterima yaitu ada hubungan kecanduan internet dan kecemasan komunikasi dengan karakter kerja sama pada mahasiswa.Hal ini dapat dilihat dari F hitung diperoleh sebesar 123.308 lebih besar dibanding $\mathrm{F}$ tabel yaitu sebesar 3.101 sehingga hipotesis yang diajukan diterima yaitu ada hubungan antara kecanduan internet dan kecemasan komunikasi dengan karakter kerja sama pada mahasiswa.

Korelasi secara parsial kemudian dilakukan dengan uji koefisien regresi secara parsial. Pengujian korelasi parsial antara kecanduan internet dengan karakter kerja sama diperoleh bahwa $\mathrm{t}$ hitungyaitu $2.043>\mathrm{t}$ tabel yaitu 1.987 sehingga secara parsial ada hubungan kecanduan internet dengan karakter kerja sama. Pengujian korelasi parsial berikutnya antara kecemasan komunikasi dengan karakter kerja sama diperoleh hasil $\mathrm{t}$ hitung yaitu $2.927>\mathrm{t}$ tabel yaitu 1.987 sehingga secara parsial juga ada hubungan kecemasan komunikasi dengan karakter kerja sama pada mahasiswa. Hasil tersebut menunjukkan bahwa dalam penelitian ini bila dilihat secara parsial variabel kecemasan komunikasi lebih berpengaruh bila dibandingkan dengan variabel kecanduan internet dalam hubungannya dengan karakter kerja sama.

Berdasarkan hasil uji analisis regresi linier berganda diperoleh angka R Square sebesar 0,888 hal ini menunjukkan bahwa presentase sumbangan pengaruh variabel bebas terhadap variabel tergantung sebesar $88,8 \%$ apabila kedua variabel bebas tersebut bersama-sama dalam memengaruhi variabel tergantung.

\section{Diskusi}

Pada penelitian ini diperoleh hubungan yang kuat antara kecanduan internet dan kecemasan komunikasi dengan karakter kerja sama pada mahasiswa. Kerja sama membutuhkan empat hal pokok yang meliputi pembagian tugas, memiliki inisiatif, interaksi sosial yang aktif, dan kemampuan berkomunikasi secara efektif (Ikhwanudin, 2011). Pada penelitian ini telah diteliti dua faktor turunan yaitu kecanduan internet turunan dari interaksi sosial yang buruk dan kecemasan komunikasi yaitu turunan dari kurangnya kemampuan berkomunikasi. Kedua faktor yang diteliti dalam penelitian ini memiliki korelasi yang kuat dengan karakter kerja sama pada mahasiswa. 
Mahasiswa yang memiliki karakter kerja sama yang rendah akan berdampak negatif dalam menjalankan tugas perkembangan selanjutnya karena pada tahap tersebut mahasiswa harus banyak melakukan penyesuaian diri. Menurut Prihati (2011) pada usia mahasiswa yaitu masuk dalam tahap remaja akhir banyak penyesuaian yang harus dilakukan diantaranya penyesuaian metode belajar yang berbeda antara SMA dan universitas, penyesuaian dalam hubungan sosial dan peran di masyarakat, penyesuaian dalam masalah ekonomi serta penyesuaian diri terhadap pemilihan jurusan.

Karakter kerja sama merupakan karakter yang penting bagi petugas pelayanan kesehatan. Kerja sama terjadi ketika tenaga profesional kesehatan fokus pada perawatan pasien, pemecahan masalah, koordinasi perawatan, belajar bersama, dan jaringan di masyarakat, dalam rangka mengoptimalkan kualitas perawatan bagi pasien dan keluarga. Karakter kerja sama merupakan prioritas organisasi kesehatan dunia (McCallin dan McCallin, 2009). Karakter kerja sama perlu dimiliki tenaga kesehatan karena penting dalam memberikan pelayanan kesehatan terutama tenaga praktisi. Jika pelayanan kesehatan berkualitas adalah tujuan utama untuk pasien dan keluarga maka kompetensi klinis harus seimbang dengan kompetensi karakter. Tantangan utama untuk karakter kerja sama adalah kemampuan berinteraksi dengan orang lain dan kemampuan komunikasi efektif. Mahasiswa umumnya dan mahasiswa bidang kesehatan khususnya wajib memliki karakter kerja sama agar dapat meningkatkan kualitas pelayanan kesehatan saat sudah terjun ke masyarakat.

Hasil penelitian menunjukkan bahwa secara parsial terdapat hubungan kecanduan internet dengan karakter kerja sama.
Menurut Young dan Rogers (1998) Dampak negatif dari internet membuat seseorang menjadi malas untuk berinteraksi di dunia nyata karena merasa lebih menyenangkan untuk berinteraksi dengan teman online sehingga mengakibatkan kurangnya rasa empati terhadap lingkungan sekitar. Akibatnya kemampuan individu untuk berinteraksi dan sosialisasi menjadi tumpul.

Hal ini diperkuat dengan teori yang dikemukakan Soetjipto (2004) bahwa kecanduan internet memiliki gejala psikologis antara lain perasaan euforia, kemampuan mengontrol pemakaian internet, menambah waktu untuk berinternet, kemampuan bersosialisasi berkurang, depresi, suka berbohong, dan bermasalah secara sosial. Ketika individu mulai kecanduan internet, individu tersebut cenderung menarik diri dari dunia nyata.

Pola maladaptif penggunaan internet menimbulkan efek sosial (Chou et al, 2005). Efek sosial ini sangat beragam mulai dari efek di bidang akademik, hubungan sosial, keuangan, dan pekerjaan. Apabila tidak ditangani secara serius bahkan akan membuat individu lebih menyukai dunia maya dibanding dunia nyata sehingga individu menarik diri dari lingkungan sosial.

Penggunaan internet memiliki dampak terhadap pola perilaku masyarakat di perkotaan. Temuan studi menunjukkan bahwa telah terjadi evolusi penggunaan internet, dari penggunaan untuk fungsi sederhana (komunikasi) menjadi penggunaan dengan fungsi yang spesifik. Temuan studi lainnya menunjukkan bahwa pengguna internet merupakan masyarakat yang berpendidikan tinggi (well educated) dan mampu secara finansial (wellfinanced). Studi tersebut juga menunjukkan dampak yang teridentifikasi akibat penggunaan internet secara intensif dapat dibagi 
berdasarkan tiga kriteria, yaitu pola pergerakan, pola aktivitas dan implikasinya terhadap interaksi sosial (Dewi, 2011).

Kecanduan internet memiliki hubungan dengan karakter kerja sama pada mahasiswa namun demikian juga masih ada faktor lain yang berkorelasi dengan karakter kerja sama yaitu kecemasan komunikasi. Menurut Gudykunst (2002) kecemasan adalah dasar penyebab kegagalan komunikasi. Kecemasan memengaruhi kemampuan individu untuk dapat berkomunikasi secara efektif dan menyesuaikan diri dengan lingkungan yang baru. Kegagalan berkomunikasi meminimalkan terjadinya interaksi sosial dalam bekerja sama.

Gangguan dan hambatan dalam komunikasi memiliki hubungan terhadap karakter kerja sama pada mahasiswa. Hambatan komunikasi tersebut salah satunya berupa kecemasan komunikasi. Siska, dkk (2003) menyatakan bahwa kesulitan komunikasi internal dikarenakan adanya kecemasan berupa rasa takut menerima tanggapan atau perilaku negatif dari komunikan.

Kerja sama membutuhkan partisipasi aktif antara rekan satu tim. Partisipasi yang aktif membutuhkan kemampuan berkomunikasi yang lancar tanpa hambatan. Ketika individu mengalami hambatan dalam berkomunikasi maka kemampuan untuk bisa bekerja sama dengan rekan dalam tim juga akan terganggu. Menurut Soonthornsawad (2009) kecemasan komunikasi adalah perasaan takut untuk ikut berpartisipasi dalam komunikasi lisan pada situasi tertentu.

Efektivitas komunikasi hanya dapat dicapai bila antara petugas kesehatan dengan klien tercipta kerja sama yang baik untuk mencapai satu tujuan (Basuki, 2010). Tanpa kemampuan berkomunikasi yang efektif antara anggota dalam tim maka kerja sama akan sulit dilakukan. Hambatan dalam komunikasi menyebabkan pesan tidak dapat diserap secara optimal akibatnya informasi yang dibutuhkan antara individu dalam satu kelompok terlewatkan satu dengan yang lain sehingga kerja sama tidak berjalan dengan lancar.

Kecemasan komunikasi dalam setting akademik dapat memengaruhi prestasi dan kinerja serta pembangunan sosial dan psikologis (Cowden, 2010). Kecemasan komunikasi harus diatasi sedini mungkin agar prestasi belajar tidak terganggu serta tidak terbawa ke dunia kerja saat mahasiswa sudah lulus dan menjadi pekerja di suatu institusi.

Bekerja sama membutuhkan komunikasi antara individu yang satu dengan yang lainnya. Komunikasi yang dilakukan dapat berupa komunikasi verbal maupun non verbal, lisan maupun tertulis, yang pasti tidak hanya antara individu namun juga individu dengan kelompok atau tim. Bila hal ini tidak berjalan dengan lancar maka karakter kerja sama juga sulit untuk dimunculkan. Powell \& Powell (2010) menjelaskan kecemasan komunikasi sebagai tingkat ketakutan individu yang diasosiasikan dengan situasi komunikasi, baik komunikasi yang nyata ataupun komunikasi yang akan dilakukan individu dengan orang lain maupun dengan orang banyak.

Berdasarkan hasil uji korelasi parsial nampak bahwa variabel kecemasan komunikasi lebih berperan pada karakter kerja sama dibanding variabel kecanduan internet. Menurut Alsa (2010) kerja sama dapat berjalan meliputi lima hal yaitu adanya penerimaan orang lain terhadap diri sendiri, adanya penerimaan diri sendiri terhadap orang lain, interaksi antar anggota kelompok, kemampuan komunikasi serta adanya koordinasi pembagian 
tugas. Variabel kecemasan komunikasi lebih berperan karena kemampuan komunikasi dan penerimaan diri merupakan faktor internal individu yang lebih sulit untuk dirubah sedangkan variabel kecanduan internet yang masuk dalam interaksi antar anggota kelompok dan koordinasi pembagian merupakan faktor eksternal yang lebih mudah dikendalikan.

\section{Kesimpulan}

Berdasarkan hasil analisis data diperoleh kesimpulan bahwa kecanduan internet dan kecemasan komunikasi secara bersama-sama maupun parsial berpengaruh terhadap karakter kerja sama pada mahasiswa. Pada penelitian ini dampak penggunaan internet lebih disoroti mengenai implikasinya terhadap interaksi sosial, terbukti bahwa terdapat hubungan antara kecanduan internet terhadap karakter kerja sama. Namun demikian ada beberapa faktor dalam penelitian ini yang tidak dapat dikontrol seperti pembagian tugas dan inisiatif. Hal ini dikarenakan kedua faktor tersebut tidak diteliti dalam penelitian ini. Selain faktor jenis kelamin juga menjadi hal yang sulit dikontrol karena mahasiswa di bidang kesehatan mayoritas adalah perempuan demikian halnya dalam penelitian ini sampel yang digunakan juga mayoritas perempuan. Bilamana kedepan dilakukan penelitian serupa maka jika kondisi memungkinkan dapat dilakukan dengan jenis kelamin yang sebanding antara laki-laki dan perempuan sehingga dapat diteliti lebih mendalam apakah faktor jenis kelamin berpengaruh dalam penelitian ini.

\section{Saran}

Berikut ini saran yang dapat disampaikan penulis terkait hasil penelitian yang diperoleh: saran bagi pendidik sebaiknya mengurangi bahan mengajar yang menggunakan metode online, namun tidak berarti metode online harus dihilangkan melainkan dilakukan pembatasan, untuk buku dan bahan ajar yang bisa diprintoutkan sebaiknya dicetak, mengubah mind set bahwa online itu keren karena menumpulkan kemampuan bersosialisasi, menggunakan metode mengajar yang mengasah kemampuan berkomunikasi sehingga mahasiswa bisa belajar bekerja sama, memperdalam penelitian dengan melakukan penelitian lanjutan terkait cara mengatasi kecemasan komunikasi maupun cara menumbuhkan karakter kerja sama.

\section{Kepustakaan}

Alsa, A. (2010). Pengaruh metode belajar jigsaw terhadap ketrampilan hubungan interpersonal dan kerja sama kelompok pada mahasiswa fakultas psikologi. Jurnal Psikologi UGM, 37(2), 165-175.

Basuki, E.S.M. (2010). Komunikasi petugas kesehatan dengan klien dalam pelayanan kedokteran di Indonesia. Jakarta: Universitas Indonesia.

Burgoon, M \& Ruffner, M. (1978). Human communication. New York: Holt Rinehart and Winston.

Chou, C; Condron, L; Belland, J.C. (2005). A Review of the Research on Internet Addiction. Educational Psychology Review, 17(4), 363-389,http://dx.doi. org/10.1007/106-4-8005-8138-1.

Clarken, R. (2010). Considering moral intelligence. As part of a holistic education. Denver: Northern Michigan University.

Cowden, P. (2010). Communication and conflict: anxiety and learning. Research 
in higher education journal. Niagara: Niagara University.

Dewi, N. (2011). Hubungan Kecanduan Internet dan Kecemasan dengan Insomnia pada Mahasiswa S1 FK UNS yang sedang Skripsi. (Tesis tidak dipublikasikan). Fakultas Kedokteran Universitas Sebelas Maret, Surakarta.

Gudykunst, W.B. \& Mody, B. (2002). Handbook of international and intercultural communication, 2nd edition. London: Sage Publication, Inc.

Ikhwanuddin. (2011). Implementasi pendidikan karakter kerja keras dan kerja sama dalam perkuliahan. Yogyakarta: UNY.

Kesuma, D; Triatna, C; dan Permana, J. (2011). Pendidikan karakter: Kajian, teori dan praktik di sekolah. Bandung: P.T Remaja Rosdakarya.

McCallin, A; McCallin, M .(2009). Factors influencing team working and strategies to facilitate successful colaborative teamwork. NZ Journal of Physiotherapy, 37(2), 61-67.

Powell. R \& Powell. D. (2010). Classroom communication and diversity. New York : Routledge.

Prihati, M. (2011). Kontribusi Kepribadian Introvert Terhadap Kecanduan Internet Pada Mahasiswa. (Disertasi tidak dipublikasikan). Fakultas Psikologi Universitas Gunadarma, Jakarta.

Siska, Sudarjo \& Purnamaningsih. (2003). Kepercayaan diri dan kecemasan komunikasi interpersonal pada mahasiswa. Jurnal Psikologi UGM, 2(1), 6771.

Soetjipto, H.P. (2004). Pengujian validitas konstruk kriteria kecanduan internet. Jurnal Psikologi UGM, 32(2), 74-91.

Soonthornsawad, P. (2009). Cultures and genetic markers as predictors of. communication apprehension. Hawaii: Master of Arts in. Communication.

Spencer, M.L \& Spencer, M.S. (1993). Competence at work: Models for superrior performance. New York: John Wily \& Son,Inc.

Young, K.S. (1998). Internet addiction: The emergence of a new clinical disorders. CyberPsychology \& Behavior, 1(3). doi: 10.1089/cpb.1998.1.237

Young, K.S., \& Rodgers, R.C. (1998). The relationship between depression and internet addiction. Cyberpsychology $\mathcal{E}$ Behavior. 1(1). doi: 10.1089/ cpb.1998. 1.25

Zuchdi, dkk, (2009). Pendidikan karakter. Yogyakarta: UNY Press. 